Tips om medisinsk litteratur, andre bøker, filmer og elektroniske medier som bør anmeldes, sendes tidsskriftet@legeforeningen.no

\section{Lepralegen som satte spor etter seg}

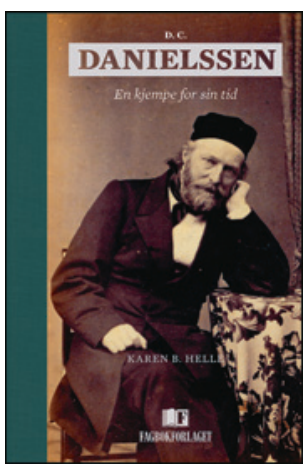

Karen B. Helle

\section{D.C. Danielssen}

En kjempe for sin tid. 206 s, ill. Bergen

Fagbokforlaget, 2014. Pris NOK 399

ISBN 978-82-450-1584-3

Få mennesker har satt så mange spor etter seg som legen Daniel Cornelius Danielssen (1815-1894). Det gjelder både som lege, naturforsker og kulturmenneske i Bergen, det gjelder nasjonal innsats som politiker og forkjemper for lepraomsorgen, og det gjelder internasjonalt som lepraforsker. Han var aktiv som politiker og satt en tid på Stortinget, han var en av de førende i Bergens kulturliv, og han ledet Bergen Museum i en årrekke og deltok i biologisk forskning. Bergen Museum som forskningsinstitusjon ble siden en viktig pilar for det nye universitetet, noe som først og fremst er Danielssens fortjeneste.

Lepra var en sykdom som økte betydelig i første halvdel av 1800-tallet, og en av Danielssens oppgaver da han ble tilsatt ved St. Jørgens Hospital i Bergen i 1839, var å utforske sykdommen og prøve å finne en årsak til den. Sammen med Carl Wilhelm Boeck ga han i 1847 ut et bokverk med tittelen Om Spedalskhed, som siden ble oversatt til andre språk. Det var den første systematiske beskrivelsen av sykdommen, basert på nøye klinisk observasjon og om-fattende obduksjoner. Danielssen beredte også mye av grunnen for at en annen kjent bergenslege, den noe yngre Gerhard Armauer Hansen, oppdaget leprabasillen i 1873. Internasjonalt har Danielssen fortsatt et stort renommé, og det kommer gjester til Bergen fra alle verdens kanter for å se hvor disse to lepraforskerne arbeidet.

Likevel er det et paradoks at en mer omfattende biografi over Danielssen hittil ikke har vært utgitt. Karen Helle var mange år professor i fysiologi ved Universitetet i Bergen. Hun har hatt et omfattende, delvis nyoppdaget historisk materiale til rådighet, og med denne boken har hun reist et stort minnesmerke over Danielssen. Det er en høyst leseverdig biografi over en av de mest mangslungne personlighetene i norsk akademia. Hun gir også et bredt bilde av innsatsen hans innen medisin, biologi og kultur.

Boken er nøkternt skrevet og gir et vell av informasjon om en person som hadde stor betydning i samtiden. Den er rikelig illustrert med gamle fotografier som gir en fin tidskoloritt. Biografien over Danielssen kan sterkt anbefales til alle med interesse for medisinsk historie, og spesielt gjelder det leprahistorien der Norge har en sterk internasjonal posisjon. Den kan også anbefales for lesere med interesse for vitenskapshistorie og for norsk kulturliv på 1800tallet, selv om en god del av stoffet først og fremst har lokal interesse for Bergen. Det er god grunn til å gratulere forfatteren med arbeidet.

\section{Ole Didrik Lærum}

Professor emeritus, Klinisk Institutt 1

Gades Laboratorium

Universitetet i Bergen

\section{Når hjernen svikter}

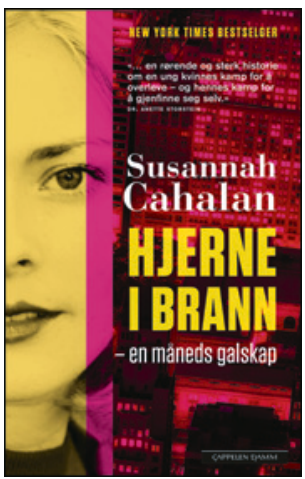

Susannah Cahalan

Hjerne i brann

En måneds galskap. 312 s. Oslo: Cappelen

Damm, 2014. Pris NOK 349

ISBN 978-82-02-43721-3

Den 24 år gamle journalisten Susannah Cahalan skriver for New York Post. Med denne gripende patografien har hun sørget for at anti-NMDA-reseptor-encefalitt, en sjelden nevrologisk sykdom, har fått et ansikt.

I en studie fra 2008 undersøkte man 100 pasienter med samme sykdom og fant at median alder var 23 år og at $91 \%$ var kvinner (1). Vanlige symptomer omfatter hukommelsesproblemer, epileptiske anfall, nedsatt bevissthet, motoriske forstyrrelser og atferdsendringer. Årsaken er ukjent. Én av fire med tilstanden dør.

Boken er tredelt og innledes med at Cahalan, i litt Woody Allenaktig stil, analyserer og overtolker egne tanker mens hun vandrer rundt $\mathrm{i}$ gatene på Manhattan, med en vedvarende følelse av at noe skurrer i topplokket. Forfatteren lykkes godt med å skildre egne mentale endringer, blant annet å rote med arbeidsoppgaver, være unødvendig tverr på hjemmefronten og heller ikke sette pris på å være sosial med venner. Cahalan blir stadig verre og innlegges til slutt på sykehus, hvor hun beskrives som overveiende psykotisk. Hun blir tungt medisinert. Cahalan har nesten ikke språk, er forvirret og har hukommelsessvikt, men blod- og urinprøver er normale, og ingen finner avvikende funn på bilder av hjernen (CT og MR). Man oppdager kun lett forhøyet nivå av hvite lymfocytter i spinalvæskeprøven. Psykiaterne mener at tilstanden må være knyttet til en psykisk lidelse. En nevrolog er derimot ikke like sikker og starter opp behandling med steroider og immunoglobuliner. Det skal vise seg å bli livreddende.

Del to er den mest fascinerende og har den passende tittelen Klokka. En aha-opplevelse inntreffer da en velkjent, men enkel kognitiv test, nemlig klokketesten, tas i bruk. Cahalan tegner samtlige tall på høyre side av klokkeskiven, og dermed konkluderer den kloke legen med at den høyre hjernehalvdelen fungerer langt under pari. En hjernebiopsi bekrefter diagnosen anti-NMDA-reseptor-encefalitt. Forfatteren vier del tre til rehabiliteringsperioden, og hun ivrer etter å fortelle om bedring av kognisjon, og hun reflekterer over livet som et friskt menneske.

Cahalan ble behandlet ved et av de beste sykehusene i USA, og legen som skjønte tegningen og behandlet Cahalan, ble kåret til en av USAs beste nevrologer av New York Magazine (uten at det nevnes hvilke kriterier som lå til grunn for avgjørelsen). Boken kan varmt anbefales, spesielt oppfordres helsepersonell innen psykiatri og nevrologi til å lese den. Hvordan ville denne unge journalisten blitt undersøkt, diagnostisert og behandlet dersom hun hadde bodd i Norge, og ikke i Hell's Kitchen, New York?

Tor Rosness

Tidsskriftet

\section{Litteratur}

1. Dalmau J, Gleichman AJ, Hughes EG et al. Anti-NMDA-receptor encephalitis: case series and analysis of the effects of antibodies. Lancet Neurol 2008; 7 : $1091-8$ 